This is more than can be said for some neighbouring countries.

The layman will find much profit and pleasure in studying the plates, but to read the text requires more detailed knowledge than he could possess. The attempt to squeeze so much into so small a space entails a style which at times becomes almost telegraphic in its compression. It also necessitates allusions which are sufficient for the Egyptologist, but must be meaningless to the public. Again, it induces a statement as of fact of much that really needs a discussion which would result in a probability, or perhaps only in a possibility. The system of dates used is the author's own, which is much longer than anything accepted by others. In putting Menes to 4326 B.C., Sir Flinders Petrie puts him a thousand years or more earlier than would anyone else, though even this is a thousand years later than he used to date him. G. A. WAINWRIGHT.

\title{
Universities of the British Empire
}

The Yearbook of the Universities of the Empire, 1939 (Published for the Universities Bureau of the British Empire.) Pp. xlv+1197. (London: G. Bell and Sons, Ltd., 1939.) 15s. net.

$\mathrm{IN}^{\mathrm{N}}$ its main outlines the Universities Yearbook retains the shape given to it twenty-five years ago by its original designers. Its principal features are still : a directory of the officers and members of the staff of each university, general information as to origin, organization, equipment, courses of study, etc., and reports of events of outstanding interest which occurred during the past academic year. The reports, by the way, are in some cases excessively meagre, even such an important university as Bombay, for example, reporting nothing more than the total number of full-time students and the number of degrees conferred.

Preceding the sections dealing with the universities of Great Britain and Ireland, of Canada, of Australia, of South Africa and of India, respectively, are introductory chapters treating briefly of their history, regulations and practice. The first of these, which has a rather jejune appearance, concludes with an interesting account of the genesis of a Consultative Committee of ViceChancellors and Principals. That some such body should exist to co-ordinate policy in matters of common concern and stimulate adjustments to the changing social environment and national needs is sufficiently obvious. What surprises one is that it did not exist before 1918. The chapter about the universities of Australia has been extensively revised for the present issue of the Yearbook by the Australian Vice-Chancellors' Committee.

In eleven appendixes, covering some two hundred and fifty pages, are assembled an assortment of notes on admission to universities, professional bodies, student organizations and other matters, contributing to make the Yearbook a sort of 'inquire within upon everything' connected with universities. Among them are useful particulars of post-graduate scholarships and grants for advanced study and research and centres of scientific research and information. These reflect the conspicuous defects in the organization of the finance, distribution, direction and co-ordination of scientific research in Great Britain to which Prof. J. D. Bernal has directed attention so forcibly in "The Social Function of Science" Another appendix epitomizes returns (not published elsewhere) from universities and university colleges in Great Britain and Ireland of their students from abroad. The total number, 6,214, includes 1,614 from other countries in Europe, 2,180 from Asia, 1,061 from Africa, 1,034 from America and 325 from Australasia. Of European countries the largest contributors were : Germany (532), Poland (195), Holland (77), Hungary (71), France (65) and Norway (64). Students from India numbered 1,350, from China 233, from Egypt 383, from Palestine 146, from South Africa 532, from the U.S.A. 517, from Canada 271.

The body responsible for the production of the Yearbook is the Universities Bureau of the British Empire. Full particulars of its constitution appear, together with its last annual report, on pages xixlv. An important event in the Bureau's history was the secretary's tour of the Canadian universities, which took place in the spring of last year. He visited all of them and discussed with members of their staffs ways and means whereby the Bureau could be of service to them. He returned via the United States, and while there discussed with the presidents of Harvard and Yale, the president of the Carnegie Corporation of New York and the director of the Institute of International Education, the possibility of the visit to England in 1941 of some of the heads of universities in the United States, with a view to their meeting the heads of universities in the British Empire at the congress to be held in Manchester. 